\title{
RECOGNITION OF THE POLITICAL RIGHTS OF ETHNIC MINORITIES IN EUROPEAN COUNTRIES
}

\author{
Denis I. Igonin ${ }^{1}$ \\ Ruslan F. Garipov $^{2}$
}

\begin{abstract}
This paper discusses the features of the political rights of ethnic minorities in individual European states. The relevance of the study is due to the fact that this institution is undergoing its transformation. In connection with this fact, object of research in the paper is the analysis of individual international and constitutional acts. The emphasis on ethnic minorities in revealing the essence of political rights is by no means accidental. Legislative registration as a state recognition of the rights of ethnic minorities is a prerequisite for combating discrimination and, at the same time, protecting small groups of people. Therefore, the policy in the field of these

accompanied by arguments based on modern international norms. But when referring to the main international acts, this issue does not look as clear as it is presented in a number of scientific studies. It does not at all follow from these international acts that these rights belong only to ethnic groups. The term "people" is interpreted as a community of citizens residing both in independent states and in dependent territories. Thus, it is not entirely clear whether a particular European state is obliged to exercise these rights in relation to a single ethnic group, since these international documents do not directly contain such an obligation.
\end{abstract} rights is a socially significant reality recognized today by the international community. It is the result of ethnosocial consensus. The assertion that the political rights of ethnic minorities are universally recognized is often

Keywords: ethnic group, ethnic minorities, ethnopolitology, ethnic politics, ethnic law.

\footnotetext{
${ }^{1}$ Kazan Federal University, Institute of Sociology, Philosophy and Mass Communications, e-mail: IgoninDenis1983@yandex.ru, tel: +79625490384.

${ }^{22}$ Kazan Federal University, Institute of Sociology, Philosophy and Mass Communications, email: ruslanweb@bk.ru, tel. 89503205531.
} 


\section{Introduction}

The problems of the development of interethnic relations in the context of European regionalization are connected with the political rights of ethnic minorities. The most acute topic is their recognition and implementation in individual states. These issues are currently one of the main objects of ethno-national policy in most European countries. This is largely stimulated by global migration processes that have generated a social demand for expanding the rights of ethnic minorities and solving problems in the field of interaction between different cultures and peoples.

It is no coincidence that the search for a model for the systemic integration of different ethnic groups into a single civic nation became a common European trend. This is inevitably accompanied by conflicts that states have to resolve in the shortest possible time. It is the political and legal sphere that is called upon to minimize the negative effect of such phenomena, as well as to prevent the emergence and growth of new social exacerbations on ethnic grounds.

\section{Methods}

The methodological basis is a systematic and functional study of the political rights of ethnic minorities. As a result of this, it is customary to single out several approaches to their concept.

Over the past decades, the phrase "collective political rights" is used not only in Western [1;2], but also in Russian science [3; 4]. Modern researchers differently interpret this concept in the prism of ethnic groups. As some authors note, this term means a set of individual political rights, which in the process of their realization acquire a collective character, i. e. require joint implementation with others [5]. Other scholars consider such rights common to any person and citizen [6]. This position is rejected by adherents of the approach, according to which an emphasis is necessary on the special, and not on the general nature of the rights belonging to individuals within a certain social category $[7 ; 8]$. The corporate element in the disclosure of the essence of collective political rights is highlighted by those specialists who consider their carriers as an organization [9]. Based on this, 
individual authors determine collective political rights in the sphere of the rights of a single social community, thereby putting an equal sign between them and group rights [10].

\section{Results And Discussion}

Within the European Union, there is a formula in force which defines that the rights of ethnic groups are the prerogative of a European state itself. It may, but does not have to, follow the recommendations of European structures regarding the realization of certain interests of ethnic minorities.

Those issues are discussed at the highest political level since the middle of 1990s. In particular, then the European Commission presented the Euromosaic report. It presented the following indicators: ethnic minorities make up about $8 \%$ of the population of the EU countries, which at the time of the presentation was expressed in 30 million people [11]. It is noteworthy that then only 12 states were part of a united Europe. At the same time, the report noted the fact that out of about 48 languages of ethnic groups that are minorities in the EU, 23 languages were at the stage of extinction [11].
Examples of individual European states demonstrate a complete disregard for the existence of ethnic or linguistic groups within the framework of constitutional and other legislation. It does not matter if such groups belong to minorities or not. Thus, in France, the idea of the private-law nature of ethnicity is postulated. Based on this, everything that affects ethnic identity, religion and language is not subject to public law, since it constitutes the personal sphere of a citizen, i. e. is regulated by laws aimed at determining the procedure for the use of personal rights and freedoms.

The policy of non-recognition of the ethnic groups' rights was clearly demonstrated in 1991 by the French Constitutional Council, which recognized as non-compliant with the Constitution the 1991 Law on the provision of a special statute to the territorial group of Corsica. In particular, this document contained the wording "Corsican people", which was contrary to Article 2 of the French Constitution recognizing only the French people. The specified constitutional norm emphasizes that the people is composed of French citizens who do not have 
differences in their origin, race and religion.

In fact, ethnographic studies show that in France there are ethnic groups that are fundamentally different from the French in both their cultural and linguistic terms. For example, they are traditionally classified as Bretons, Alsatians, Walloons, Flemings, Catalans, etc. [12]. Perhaps for this reason in the practice of France of the last decade it has become the provision of certain rights for certain ethnic minorities, but exclusively within the national cultural sphere (on the use of the national language in teaching and upbringing).

In Germany, the rights of ethnic groups are assigned to the subject of federal lands. Therefore, in the constitutions of some of them, recognition of a number of minorities is observed. For example, gypsies, Danes, friezes and sorbians have the official status of an ethnic group in Germany. In the northern federal state of SchleswigHolstein, the Danes and Frisians have their own political party, the Union of Voters of South Schleswig (SSW). This organization has the privilege of getting into the Land parliament, since it is not obliged to overcome the $5 \%$ election threshold there.

The legal status of such an ethnic group as the Lusatians (Sorbians) is formally confirmed in the laws of the federal states of Saxony and Brandenburg, where this Slavic people compactly live. However, this group is deprived of the right to create its own party. It should be noted that with the existence of a socialist GDR, their individual rights were indicated in Article 40 of the Constitution of this state in 1974. In particular, it was about the possibility of citizens of the GDR of Sorbian nationality to maintain their native language and culture. Accordingly, the state was entrusted with a constitutional obligation to promote the implementation of these rights.

The practice of non-recognition of the rights of ethnic groups in some European states is simultaneously accompanied by a contradictory approach of the governments of other countries to individual national minorities. So, within the framework of one state, the legal status of ethnic groups can be regulated in completely different ways. For example, the 1990 Constitution of the Republic of Slovenia 
contains a special article that speaks about the special rights of the indigenous Italian and Hungarian ethnic groups. In accordance with Article 64 they are guaranteed with broad rights, including their special representation in the form of one deputy from a group within the framework of the State Assembly of Slovenia (Article 80). However, the Slovenian Constitution emphasizes that the rights of the gypsy ethnic group are subject to regulation by a special law.

This practice of establishing a list of ethnic groups at the constitutional level determines the situation in which other groups are excluded from the subject of legislation aimed at ensuring their protection. Therefore, most EU states try to use mainly abstract legislative criteria for classifying people as ethnic groups, especially in terms of national minorities. Thus, the method of listing them in legal acts is not effective, although it is recognized by researchers as an instrument of legitimacy of ethnic communities, which, in turn, cannot be considered a reliable guarantee of the protection of their rights.

In Europe, there are examples of affirmative action policies regarding the rights of ethnic groups. It consists in granting certain additional rights not only to certain national minorities, but also to their individual representatives. This trend is most evident in the realization of the right of an ethnic group to its political representation in power structures. Despite the fact that the constitutional legislation of European states recognizes such an opportunity for all citizens, its actual implementation rests on the preferences of the majority of the population, who do not seek to vote for representatives of national minorities.

So, to solve this problem, Article 59 of the 1991 Constitution of Romania provides a guarantee for an organisation of ethnic minorities to have one parliamentary seat, provided that after the election results the organisation does not gain a sufficient number of votes to pass to the legislative body. At the same time, there is the principle that this guarantee applies only to one such organisation representing the interests of the ethnic group in elections.

A more detailed norm is contained in Article 18 of the 1991 Constitutional Law "On Human Rights and Freedoms and Rights of Ethnic and national communities or minorities in the 
Republic of Croatia". According to it, if an ethnic group accounts for over $8 \%$ of the population of Croatia, then it has the right to political representation in republican authorities (in parliament, government and courts) in proportion to the number of its members. If an ethnic group is less than $8 \%$ of the total population of Croatia, then such a group has the right to elect five deputies to the House of Representatives of the Republican Parliament. Also, ethnic groups have the right to represent themselves in local governments in the proportion that they account for from the total number of residents of the respective settlement.

It is noteworthy that Croatian law complicates the process of adopting those laws that relate to the rights of ethnic groups. In particular, such laws can be adopted exclusively by a qualified majority of votes in the amount of at least two-thirds of the total number of deputies of the House of Representatives. Thus, the state confirms the special nature of issues affecting the rights and interests of ethnic groups.

In some states, specialized advisory bodies functioning under government bodies have been created to exercise the right of ethnic groups to political representation. For example, councils of national minorities of Austria operate under the auspices of the Federal Chancellor for consultation purposes. They carry out information and analytical functions for adoption of decisions by the federal government, as well as by ministries, regarding the interests of ethnic groups. In addition, these councils advise regional governments, but only in cases where they themselves ask them to do so.

\section{Summary}

The practice of establishing at the constitutional level a certain list of ethnic groups determines the situation in which other groups are excluded from the subject of legislation aimed at ensuring their protection. Therefore, most states of the European Union try to use mainly abstract legislative criteria for classifying certain people as ethnic groups, especially with regard to national minorities. Thus, the method of listing them in legal acts is not effective, although it is recognized by researchers as an instrument of legitimacy of ethnic communities, which, in turn, cannot be considered a reliable guarantee of the 
protection of their rights. The model for regulating the rights of ethnic groups in the Russian Federation, in general, is built on the same patterns that are observed in modern Europe. The key principle is an equal approach to all ethnic groups living in Russia, which is expressed in the absence in the constitutional norms of a separate group of rights granted to any ethnic groups.

\section{Conclusion}

Since the rights of ethnic groups in Europe are the exclusive subject of jurisdiction of states, and not international organizations, the Federalist Union of European Nationalities is involved in solving this problem at the interstate level. On September 5, 2017, members of this organization made a proposal to strengthen the protection of the rights of ethnic groups in Europe. In 2018, this union collects signatures in support of its project, after which it intends to demand its consideration at the level of EU institutions.

At the same time, issues of consolidation and observance of the rights of ethnic minorities were far from always ignored at the European level. So, within the framework of the Copenhagen meeting back in June 1993 the European Council, while developing standards for EU accession candidates, has identified minority rights as a priority along with respect for human rights. In particular, upon joining the European Union, the countries of Central and Eastern Europe required that national governments achieve, among other things, respect and protection of minority rights. However, already in 2000, when the Charter of Fundamental Rights of the EU was adopted in Nice on the basis of the European Council, there was no such requirement regarding the rights and interests of ethnic groups.

On the contrary, in 2004 , at a special ceremony in Rome, representatives of European states and governments signed an agreement that established the so-called "The Constitution of Europe". Its text contained in Articles 1 and 2 the provisions on the rights of ethnic minorities: "The Union is based on values such as respect for human dignity, freedom, democracy, equality, the rule of law and respect for human rights, including the rights of members of minorities." These common values unite 
the participating countries in a society where pluralism, non-discrimination, tolerance, justice, solidarity and equality between men and women triumph." However, as you know, the "European Constitution" did not enter into force due to the refusal of individual countries to ratify it on their territory. Therefore, the idea of supranational control over the observance of the rights of ethnic groups in the EU remained without its implementation.

\section{Acknowledgements}

The work is performed according to the Russian Government Program of Competitive Growth of Kazan Federal University.

\section{References}

McDonald L.E. "Collective rights as constitutional rights". York University (Canada), 1998. p. 16.

Holder C.L., Corntassel J.J. "Indigenous people and multicultural citizenship: bridging collective and individual rights", Human Rights Quarterly, vol. 24, № 1, pp. 126-151, 2002.
Sanders D. "Collective rights", Human

Rights Quarterly, vol. 13, pp. 368-386, 1991.

Tarbastaeva I. S. "Collective Rights of Ethnic Communities: Problems of Conceptualization", Siberian Philosophical Journal, vol. 14, No. 1, pp. 106-119, 2016.

Mirskaya T. I. "On the concept of collective rights", State and Law, No. 11, pp. 95-100, 2015.

MacDowell EG "Juridical action for the protection of collective rights and its legal impact: a case study", Journal of Law, Medicine and Ethics, vol. 30, No. 4, p. 644, 2002.

Peck A. "Standing for protection of collective rights in the European Communities", George Washington International Law Review, vol. 32, No. 3, p. $367,2000$.

Thompson R.H. "Ethnic minorities and the case for collective rights", American Anthropologist, vol. 99, No. 4, pp. 786798, 1997. 
Ketley H. "Exclusion by definition:

access to international tribunals for the enforcement of the collective rights of indigenous peoples", International Journal on Minority and Group Rights, vol. 8, No. 4, pp. 331-368, 2001.

Guelke A. "Ethnic rights and majority rule: the case of South Africa ", International Political Science Review, vol. 13, No. 4, pp. 415-432, 1992.

Martynova M. Yu. , Kabitsky M. E. "Minority Europe - Minorities in Europe: Ethnocultural, Religious, and Linguistic Groups", Moscow: Institute of Ethnology and Anthropology. N. N. Miklouho-Maclay RAS, 2016, 302 p.

Majstorovic S. "Politicized ethnicity: a subjective framework", University of Colorado at Boulder, 1993, P. 62 